\title{
Historical perspectives of The American Association for Thoracic Surgery: Frank C. Spencer
}

\author{
Abe DeAnda, Jr, MD, and Aubrey C. Galloway, MD
}

Frank Cole Spencer, the 63rd president of The American Association for Thoracic Surgery (AATS), was born on December 21, 1925, outside the Texas town of Haskell, which remains a small farming and ranching community. Spencer was home schooled by his mother in reading, writing, and multiplication tables and entered a 2-room schoolhouse at the age of 6 to begin first grade. The school was 3 miles from home, and the only transportation was by horseback. Spencer rode alone every day to school, but he rode bareback, without a saddle. His father felt that a saddle could be dangerous if he fell and caught his foot in the stirrup. Within weeks, Spencer was advanced to the third grade, a consequence of his mother's efforts to prepare him for school. He attributes his development of self-reliance, problem-solving, and strong work ethic to his early rural life. "My good fortune evolved from very modest circumstances in the farming country of Western Texas. It resulted from the combination of access to good education, good teachers, and a lot of hard work." ${ }^{1}$ Spencer graduated from Haskell High School at the age of 15, and while less than $10 \%$ of his fellow high school graduates went on to college, he was motivated to follow the steps of his paternal grandfather, who had been a physician. Unfortunately, years earlier when his grandfather died, he left the family with numerous debts, requiring Spencer's father to drop out of school to run the family farm. Despite this, or perhaps because of it, Spencer's father encouraged him to pursue his dream of attending college and going on to the medical profession.

Spencer was the youngest freshman at North Texas State College, now the University of North Texas. ${ }^{2}$ After settling in, and after a brief stint at a nearby soda shop, he came to the notice of James L. Carrico, the chairman of the Department of Chemistry. Dr Carrico offered him a position as his laboratory assistant and instilled him with "the excitement of learning." During this time, the United States entered World War II, and the school year was expanded to include summer and winter terms. As a result, Spencer completed his degree in $2 \frac{1}{2}$ years. He studied chemistry and mathematics and credits the teaching environment for stimulating his

\footnotetext{
From the Department of Cardiothoracic Surgery, New York University-Langone Medical Center, New York, NY.

Disclosures: Authors have nothing to disclose with regard to commercial support.

Received for publication Sept 8, 2010; accepted for publication Sept 15, 2011; available ahead of print Oct 12, 2011.

Address for reprints: Abe DeAnda, Jr, MD, Department of Cardiothoracic Surgery, NYU-Langone Medical Center, 530 First Ave, Suite 9V, New York, NY 10016 (E-mail: abe.deanda@nyumc.org).

J Thorac Cardiovasc Surg 2013;145:906-908

$0022-5223 / \$ 36.00$

Copyright (c) 2013 by The American Association for Thoracic Surgery

doi:10.1016/j.jtcvs.2011.09.012
}

intellectual curiosity. Spencer never forgot the educational and motivational stimulation he received at college and created the Frank C. Spencer Rural Student Scholarship Program at the University of North Texas years later to help underprivileged students with a similar upbringing from a "highly rural Texas county.",

His final year of college was a critical period for Spencer. With the war raging, Spencer had obtained an officer's commission in the navy, contingent on his attending medical school. Without a medical school acceptance, he would have been eligible for the draft and, in his words, “...probably in the South Pacific." He applied to the 2 medical schools in Texas and was rejected by both, not because of academic issues but because, at the time, he was only 17 years old and they thought he was too young. One afternoon on campus, Spencer overheard a classmate mentioning his plans to attend medical school at Vanderbilt University, and although he professes he had no idea where Vanderbilt was located, he mailed in an application and his transcript. Three weeks later he received a note that read, "Congratulations, you have been accepted and there is a $\$ 50.00$ deposit required." 3 He comments today that this note “...made me a lifelong Vanderbilt enthusiast!" Spencer entered medical school shortly before his 18 th birthday in December 1943.

Vanderbilt provided an environment in which Spencer could flourish. He relished the close relationships developed between the faculty and students with such a small class, approximately 45 students, and excelled in his studies, earning Alpha Omega Alpha and eventually the Founders Medal, which is given to the valedictorian of the graduating class. As his third year was getting underway, the dean of the Medical School assigned Dr Cobb Pilcher, neurosurgeon, as his advisor. When Spencer expressed a desire to do an internship on the East Coast, for no other reason than that he had heard that the best programs were located there, his application to Johns Hopkins was accepted, aided by the fact that Pilcher and Alfred Blalock, 30th AATS president, were good friends dating back to the 15 years Blalock was on the faculty at Vanderbilt. It was also at Vanderbilt, during his junior and senior years, that Spencer met Connie Ewell, an undergraduate whom he would later marry. She was a Southern belle from a well-to-do family in Coffee County, Tennessee, and as Spencer puts it, "Her family was concerned that she married an impoverished medical student!"3

Dr Spencer arrived in Baltimore in 1947 and entered a system that today's residents-in-training would consider draconian; interns were on call 7 days a week, 24 hours 


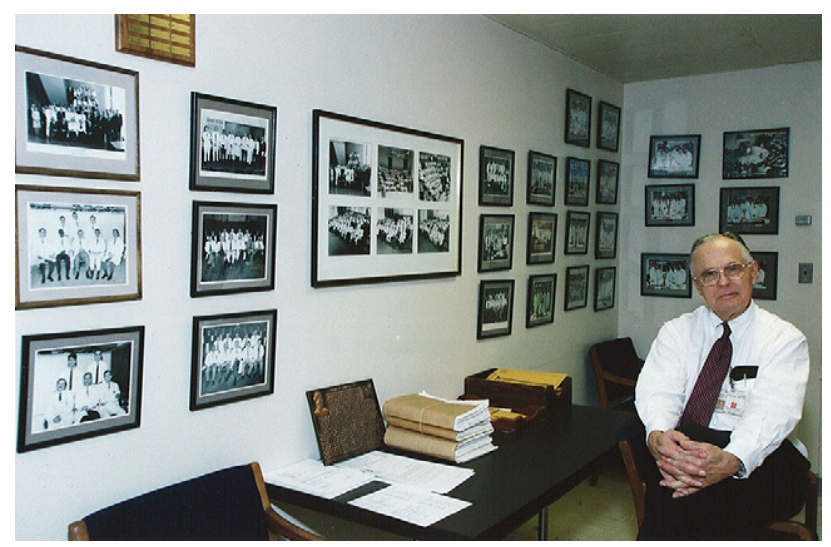

FIGURE 1. Dr Frank Cole Spencer (photo courtesy of Dr Spencer).

a day. Shakespeare notes that "...misery acquaints a man with strange bedfellows," " and the shared misery among the Hopkins residents was tempered by the concomitant esprit de corps. Spencer's intern group included David Sabiston, 65th AATS president, and James Maloney. The junior and senior residents included Henry Bahnson, 57th AATS president, Glenn Morrow, and Rollins Hanlon. Denton Cooley and Harry Muller had also recently been discharged from the army and returned as senior assistant surgeons.

Unfortunately, Hopkins had an aggressive pyramidal system, with 10 interns vying for only 2 residency positions. After his intern year, Spencer was neither selected to continue nor dismissed and spent the following year in limbo, working with Vivien Thomas in the experimental surgery and catheterization laboratories. The following year, Spencer left Hopkins to continue his training at the University of California, Los Angeles (UCLA), in William Longmire's new program. While he was at UCLA, the Korean Conflict broke out and Spencer, who still held his naval commission, was called to active duty at the Oakland Naval Base. He was initially assigned to a busy surgical service of patients with vascular injuries, which would turn out to be providential for both Spencer and his patients. Based in part on his experiences in the catheterization laboratory at Hopkins, he began performing aortography and was asked to establish a laboratory at the naval base to address vascular trauma. Before the project could be completed, he was sent to Korea as the chief of surgery in a forward marine unit: EZ Medical Company, 1st Medical Battalion-the "Cheaters of Death" (Figure 1).

Years prior, based on their experiences during World War II, DeBakey and Simeone ${ }^{4}$ had concluded that arterial injuries were best treated by ligation of the affected vessel with amputation, rather than primary repair. Consistent delays in getting wounded soldiers to the appropriate surgical environment in World War II, an average of 10 hours, led to the development of gangrene, rhabdomyolysis, and subsequent renal failure with death in many cases if arterial repair was performed. At the onset of the Korean Conflict, ligation was the accepted practice and, in fact, was official policy of the US Navy. Spencer saw his first young patient with a femoral artery injury fresh off the front, which was only 2 miles behind enemy lines in the demilitarized zone near the truce talks that were occurring at Panmunjom. Spencer was faced with the dilemma of following official orders, which would require removing potentially salvageable limbs, or tempting court-martial by performing primary repair. He chose the latter, and with a success rate approaching $90 \%$ over time, it became apparent that he had chosen wisely. "Why did I do this?" he later questioned. "It was simply a reflex-do what's best for the patient, not what's best for you!" 5 Spencer was awarded the Legion of Merit award for his efforts but, much to his chagrin, also became a "phenom" as the consequence of numerous newspaper articles that gave him credit for this daring approach. The stories were initially sent over all 3 wire services by a sneaky reporter visiting the unit who Spencer thought he was telling stories to off the record. To this day, Spencer remains “...embarrassed and angry because they didn't give any credit to my colleagues or the corpsmen and nurses, and it made me out to be a boy hero."

On returning to the United States, Spencer was stationed at Bethesda Naval Hospital when he received word that Dr Blalock wanted to speak with him. Spencer had left Hopkins disenchanted without plans to return. At the time, he was going to continue his training at UCLA, but with Longmire assigned to the Air Force in Europe, Spencer accepted Blalock's offer to return to Hopkins as a senior resident. As with many Hopkins trainees, Spencer flourished under the unassuming guidance of Blalock and, after his residency, he stayed on as faculty from 1955 to 1961, primarily developing a vascular surgery service while Henry Bahnson focused on the open heart program. In a manner that would later mirror his own approach to faculty development, Blalock would assign Spencer projects to explore, both clinically and in the experimental laboratory, with minimal interference, often despite Blalock's initial skepticism in the eventual outcome of these often cutting-edge ideas.

Spencer spent 5 years at the University of Kentucky building a new program before he accepted his ultimate position as the George David Stewart Professor and Chairman of Surgery at New York University (NYU) in 1966. NYU at that time did not have a cardiothoracic surgery service so, as was typical of Spencer, he started again from scratch. Spencer's first resident at NYU was George Green, who studied direct revascularization with the left internal thoracic artery. Spencer had initial misgivings because of his experimental work that suggested that the thoracic artery would be too small to make a significant difference. ${ }^{6}$ Green, after receiving permission from Spencer, performed the first internal thoracic-left anterior descending bypass at the Manhattan Veterans Hospital in February 1968. ${ }^{7}$ In many ways, Green 


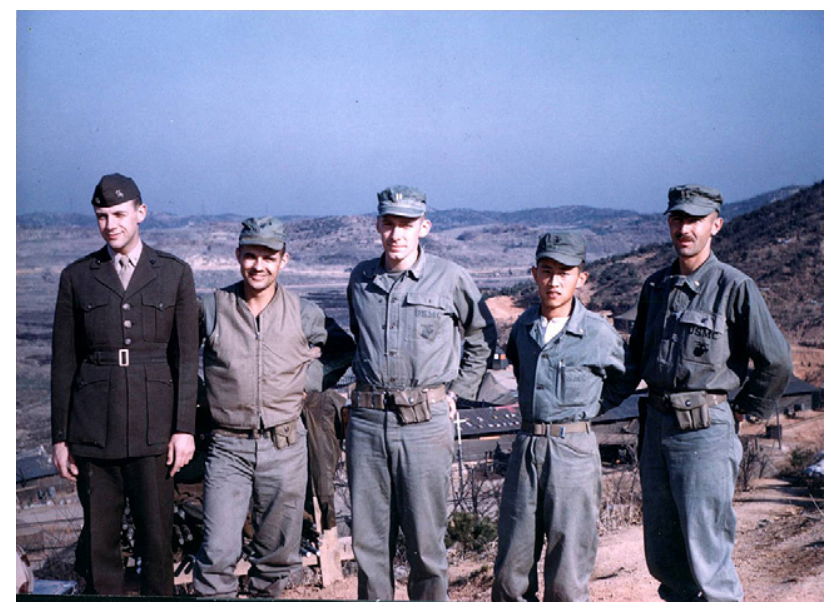

FIGURE 2. Surgical team, South Korea circa 1952. Dr Spencer is second from the left (photo courtesy of Dr Spencer).

was reprising the role Spencer had played in Korea, moving forward with a technique that might not be successful, while Spencer was reprising the role of Blalock, encouraging his junior faculty to try a novel approach despite his initial apprehension about the eventual outcome. Spencer reminds us, "My contribution [to thoracic grafting] was giving Green permission to do it, even though I thought that it was probably a waste of time.",3

Dr Spencer remained as chairman for the next 32 years, continually encouraging his staff and trainees to push the envelope.

On April 25, 1983, at the annual meeting in Atlanta, Georgia, Dr Spencer ${ }^{8}$ delivered his AATS presidential address, titled "Intellectual Creativity in Thoracic Surgeons." His address started with his reflections on 8 significant advances in cardiothoracic surgery including aortic aneurysm and prostheses, the heart-lung machine, heart valves, coronary bypass, myocardial preservation, infant hypothermia, cardiac transplantation, and closed chest massage (included because it evolved during his time at Hopkins). He based his comments on input from 19 surgeons (including 5 past AATS presidents) and 1 electrical engineer, each of whom had played an important role in Spencer's "big eight." The second half of his address summarized his thoughts on the common patterns that make a thoracic surgeon creative. He explained that the most important components that stimulate creativity are the surgeon, the environment, the idea, including its origin, development, and clinical application, and communication with others (for example, at scientific meetings). Spencer concluded that it was the surgeon who was the most important factor in the creative process-typically young, early in his or her career, and, if not a researcher, then working in an environment that emphasized and rewarded scientific investigation. He described the prototypical attitude of the innovative surgeon as "...restlessness with an unsatisfactory status quo combined with a willingness to explore the unknown with its hazards and uncertainties." He encouraged AATS members to cultivate the creative instinct and to devote a percentage of their activities to support "...the creative environment that propelled thoracic surgery to lofty heights in 1983, hopefully to even greater heights in the decades ahead." At NYU he frequently admonished, "Go out and try something new, but come back with data," and "Never be so smart that you quit."

In 1998, Spencer stepped down as chairman of the Department of Cardiothoracic Surgery but remained active both clinically and in the teaching of medical students and residents. His never-ending quest to develop the intellectual and creative potential of his students remains in the memories of all his former trainees and colleagues and continues the cycle of innovation imparted on him by Alfred Blalock. As the ultimate reward for his lifetime of dedication to patient care, teaching, research, and community service in cardiothoracic surgery, Dr Spencer was only the second recipient of the AATS Lifetime Achievement Award in 2007 (Figure 2).

We thank Dr Spencer for graciously sharing his recollections and thoughts and Dr Edward Jahnke for filling in some of the details of the Mobile Army Surgical Hospitals and vascular repair during the Korean Conflict.

\section{References}

1. Frank C. Spencer Rural Student Scholarship. Available from: http://cas.unt.edu/ advising/scholarships/frank-c-spencer-rural-student-scholarship-new-freshmen. Accessed August 27, 2011.

2. Spencer FC. The American Surgical Association: past, present, and future. Ann Surg. 1998;228:273-83.

3. Stoney WS, Frank C. Spencer, MD. In: Pioneers of cardiac surgery. Nashville: Vanderbilt University Press; 2008. p. 173-84.

4. DeBakey ME, Simeone FA. Battle injuries of the arteries in World War II. Ann Surg. 1946;123:534-79.

5. Spencer FC. Historical vignette: the introduction of arterial repair into the US Marine Corps, US Naval Hospital, in July-August 1952. J Trauma. 2006;60:906-9.

6. Spencer FC, Yong NK, Prachuabmoh K. Internal mammary-coronary artery anastomoses performed during cardiopulmonary bypass. J Cardiovasc Surg (Torino). 1964;5:292-7.

7. Green GE, Spencer FC, Tice DA, Stertzer SH. Arterial and venous microsurgical bypass grafts for coronary artery disease. J Thorac Cardiovasc Surg. 1970;60: 491-503.

8. Spencer FC. Intellectual creativity in thoracic surgeons. J Thorac Cardiovasc Surg. 1983;86:163-79. 